\title{
The relationship between suicide attempt and smoking, alcohol and substance use and psychosocial characteristics in adolescents
}

\section{Ergenlerde intihar girişimi ille sigara, alkol ve madde kullanımı arasındaki ilişki ve psikososyal faktörler}

\author{
Denizhan Bağrul1 ${ }^{1}$, Fatma İnci Arıkan²
}

'Rize Recep Tayyip Erdogan Üniversitesi, Eğitim ve Araştırma Hastanesi, Pediatri Anabilim Dalı, Rize, Türkiye ${ }^{2}$ Bozok Üniversitesi, Tıp Fakültesi, Pediatri Anabilim Dalı, Yozgat, Türkiye

Corresponding author: Denizhan Bağrul, MD, Rize Recep Tayyip Erdogan Üniversitesi, Eğitim ve Araştırma Hastanesi, Pediatri Anabilim Dalı, Rize, Türkiye

E-mail: Denizhanbagrul@hotmail.com

Received/Accepted: April 15, 2019 / April 29, 2020

Conflict of interest: There is not a conflict of interest.

\section{SUMMARY}

Objective: Our study mainly aims to identify the relationship between suicidal behavior and psychosocial factors, and smoking, alcohol and substance use habits.

Method: The study group consisted of 188 adolescents aged 13-18, who applied to Pediatric Emergency Outpatient Clinic due to suicide attempt between November 2011 and December 2012, and a control group of 142 adolescents who applied to the outpatient clinics. The Demographic Questionnaire Form and Substance Use Form employed in the study was applied to all the cases by the researcher. The cases were also asked to complete a Beck Depression Inventory.

Results: In this study, $83.2 \%$ of the suicide attempt cases consisted of girls and the mean age was 15.5 years. It was determined that, in relation to the control group, the educational life period of those who attempted suicide was shorter $(\mathrm{p}=0.002)$, they more frequently come from a divorced family $(p=0.02)$, their parents have a lower level of education $(p=0,015 ; p=0,04$, respectively), and their parents more frequently use cigarette and alcohol. Use of cigarette among those who attempted suicide was ascertained to be at a high level, which was significant in relation to the control group $(\mathrm{p}=0.001)$. Though use of alcohol and substance among those who attempted suicide were determined to be at a higher level in relation to the control group, it was not significant statistically. In cases with repeated suicide attempts, the use of cigarette, alcohol and substance was found to be increased evidently. Depression scale points of those who attempted suicide were significantly higher than that of the control group $(\mathrm{p}=0.001)$

Conclusions: It was found that various factors play a role on suicidal behavior among adolescents. In addition to demographic factors such as gender, education level, family structure, family characteristics and parents' educational level, previous suicide attempt, smoking, alcohol and substance use, depressive mood were also found to be closely correlated with suicidal behavior. Further studies on determinants of suicidal behavior and determination of risk factors will guide professionals working on this subject to foresee suicide attempts.

Keywords: Adolescent, suicide attempt, substance use; depression
Denizhan Bağrul

Fatma İnci Arıkan

ORCID IDs of the authors: D.B. 0000-0003-0375-1726 F.İ.A. 0000-0002-9139-2737 
ÖZET

Amaç: Çalısmamızın temel amacı, intihar davranışı ile psikososyal özellikler, sigara, alkol ve madde kullanım alışkanlıklarının iliş̧isini ortaya koymaktır.

Yöntem: Kasım 2011 ile Aralık 2012 tarihleri arasında S.B. Ankara Eğitim ve Araştırma Hastanesi Çocuk Acil Polikliniği'ne intihar girişimi nedeniyle başvuran, 13-18 yaşları arasındaki 188 ergen çalışma grubunu ve polikliniklere başvuran 142 ergen kontrol grubunu oluşturdu. Çalışmada kullanılan Demografik Anket Formu ve Madde Kullanım Formu araştırmacı tarafindan tüm olgulara uygulandı. Ayrıca olguların Beck Depresyon Ölçeği’ni tamamlamaları istendi. Bulgular: Bu çalı̧̧mada, intihar girişiminde bulunan ergenlerin \% 83,2'sini kız olguların oluşturuyordu ve ortalama yaş 15,5 y1 idi. İntihar girişiminde bulunanların kontrol grubuna göre eğitim süreleri daha kısa $(p=0,002)$, daha sık parçalanmış aileden geldikleri $(\mathrm{p}=0,02)$, anne ve babalarının daha düşük eğitim düzeylerine sahip oldukları $(\mathrm{p}=0,0015$, 0,04,sırasıyla), İntihar girişiminde bulunanlarda sigara kullanımı kontrol grubuna göre anlamlı olarak yüksek saptandı $(p<0.001)$. Alkol ve madde kullanımında intihar girişiminde bulunanlarda kontrol grubuna göre daha yüksek kullanım oranları saptanmasına rağmen istatistiksel olarak anlamlı değildi. Tekrarlayan intihar girişiminde bulunanlarda sigara, alkol ve madde kullanımı belirgin artmış olarak saptandı. İntihar girişiminde bulunanların kontrol grubuna göre depresyon ölçeğinden aldıkları puanlar anlamlı olarak daha yüksekti $(\mathrm{p}=0,001)$.

Sonuç: Ergenlerde intihar davranışında birçok faktörün etkili olduğu görülmüştür. Cinsiyet, eğitim düzeyi, aile yapısı, aile özellikleri, anne-baba eğitim düzeyi gibi demografik faktörlerin yanında daha önceden intihar girişiminde bulunma, sigara, alkol ve madde kullanımı, depresyon ve umutsuzluk durumunun intihar davranıșını ile yakından ilișkili olduğu saptanmıştır. İntihar girişiminin belirleyicisi olma özelliğini taşıyan bulgular konusunda yapılan çalışmaların yaygınlaştırılması ve risk faktörlerinin belirlenmesi, bu konuda çalışan profesyonellerin intihar girişimini önceden saptayabilmeleri konusunda yol gösterici olacaktır.

Anahtar sözcükler: Ergen; intihar girişimi; madde kullanımı; depresyon

\section{INTRODUCTION}

Suicide is defined as any event of death which is the direct or indirect result of a positive or negative act that the deceased attempted intentionally, knowing that it would result in death. If any such act is stopped before death occurs, it is called a "suicide attempt"1. About one million people commit suicide every year in the world. The number of deaths due to suicide each year is far more than deaths due to murder and wars. For this reason, suicidal behavior is regarded as an important public health issue all over the world. While suicides are less common in children, the frequency of suicide increases markedly with the transition to adolescence. It is suggested that increased psychiatric disorders and drug use during adolescence independently increase the risk of suicide and suicide attempts ${ }^{2,3}$.

The risk of suicide is the possibility that someone will kill himself/herself in the near future. As part of the diagnosis and treatment plan, priority should be given to assessment of this risk in individuals who are prone to suicide and attempted suicide. Many risk factors related to suicidal behavior are known and it is possible to take measures against these risk factors ${ }^{4}$.

Our study mainly aims to identify the relationship between suicidal behavior and sociodemographic characteristics, smoking, alcohol and substance use habits.

\section{MATERIAL AND METHODS}

The study group consisted of 188 adolescents aged 13-18, who applied to M.H. Ankara Training and Research Hospital, Pediatric Emergency Outpatient Clinic due to suicide attempt between November 2011 and December 2012. The control group consisted of 142 adolescents who were admitted general pediatric outpatient clinics at the same age group who did not at the time of application have a chronic disease and accepted to participate in the study. Following the completion of the required medical procedures, those among the cases who accepted to participate in the study signed an informed consent within the first week following the suicide attempt. The Demographic Questionnaire Form and Substance Use Form employed in the study was applied to all the cases by the researcher. The cases were also asked to complete a Beck Depression Inventory. "Ethical approval" was obtained from the Training, Planning and Coordination Board of the Ankara Training and Research Hospital (November 16, 2010 - decision numbered 440/3664) for the study. An "informed consent" form has been signed by all the participants' parents and themselves.

\section{Beck Depression Inventory}

This inventory was developed by Beck in 1961. It consists of a group of 21 questions that the patient should answer in order to rate the patient's depression from the cognitive perspective. It quantitatively evaluates the perceived depressive symptoms. Each symptom category consists of 
four self-assessment items. These items are scored between 0 and 3. Each question was developed on the basis of symptoms clearly visible in depressive patients. A score between 0-13 suggests no depression, a score between 14-24 suggests moderate depression, and a score of 25 suggests severe depression ${ }^{5}$.

\section{Smoking, Alcohol and Substance Use Form}

Smoking, alcohol and substance use frequencies were evaluated differently. Therefore, with a view to facilitating assessment during the analysis, "rare use" has been defined as a few times a week for smoking, 3-9 times lifetime for alcohol, and 2-5 times lifetime for other substances. "Frequent use" has been defined as daily use for tobacco, 10 or more times lifetime for alcohol and 5 or more times lifetime for other substances. This form was based on the study of Ögel et $\mathrm{al}^{7}$. In addition, the study group was questioned about smoking, alcohol and substance use by their friends and parents.

\section{Statistical analysis}

Statistical analysis of data was performed using SPSS for Windows version 15.0 package software. Chi-Square and Fisher-Exact tests were used in the analysis of categorical data, whereas Student's ttest was used in the analysis of quantitative data. Pearson's correlation analysis was employed to determine the relationship between Beck Depression Inventory and suicide attempt. Frequencies-percentages and arithmetic means were used as descriptive values for categorical data and quantitative data, respectively. The limit of significance was taken as 0,05 .

\section{RESULTS}

Sociodemographic Findings (Table 1).

Table 1. Comparison of sociodemographic characteristics of the patient and the control group

\begin{tabular}{|c|c|c|c|c|c|}
\hline & \multicolumn{2}{|c|}{ Patient Group } & \multicolumn{2}{|c|}{ Control Group } & $P$ value \\
\hline Age (years) & \multicolumn{2}{|c|}{15,5} & \multicolumn{2}{|c|}{15,7} & NS \\
\hline \multicolumn{6}{|l|}{ Gender, $(\mathbf{n}, \%)$} \\
\hline Female & 153 & 81,3 & 77 & 54,2 & \multirow[t]{2}{*}{$<0,001$} \\
\hline Male & 35 & 18,7 & 65 & 45,8 & \\
\hline \multicolumn{6}{|l|}{ Educational status (n,\%) } \\
\hline Attending primary education & 34 & 18,1 & 51 & 36 & 0,05 \\
\hline Attending High school & 122 & 64,9 & 84 & 59,1 & NS \\
\hline Attending University & 1 & 0,5 & - & - & NS \\
\hline Abandoned School & 31 & $16,5^{*}$ & 7 & 4,9 & 0,002 \\
\hline \multicolumn{6}{|l|}{ Location (n,\%) } \\
\hline Village or town & 53 & 28,1 & 26 & 18,3 & NS \\
\hline County or City Center & 135 & 71,9 & 116 & 81,7 & NS \\
\hline \multicolumn{6}{|l|}{ With whom he lived $(\mathrm{n}, \%)$} \\
\hline Parents & 155 & 82,5 & 135 & 95 & 0,04 \\
\hline Mom or dad & 32 & $17^{*}$ & 7 & 5 & $\mathbf{0 , 0 2 2}$ \\
\hline Nursing home & 1 & 0,5 & - & - & NS \\
\hline \multicolumn{6}{|l|}{ Family type $(n, \%)$} \\
\hline Nuclear family & 136 & 72,3 & 115 & 81 & NS \\
\hline Extended family & 19 & 10,1 & 20 & 14 & NS \\
\hline Scattered family & 33 & $17,5^{*}$ & 7 & 5 & $\mathbf{0 , 0 2}$ \\
\hline \multicolumn{6}{|l|}{ Income level $(\mathbf{n}, \%)$} \\
\hline Low & 141 & 75,1 & 106 & 74,6 & NS \\
\hline Moderate & 35 & 18,6 & 23 & 16,3 & NS \\
\hline Good & 12 & 6,3 & 13 & 9,1 & NS \\
\hline Total (n,\%) & 188 & 100 & 142 & 100 & \\
\hline
\end{tabular}

NS: Not significant

The study included patients aged 13-18 who applied to M. H. Ankara Training and Research Hospital Pediatric Emergency Service after a suicide attempt. Of the patients who participated in the research, $153(81,3 \%)$ were female and 35 $(18,7 \%)$ were male. The mean age of the patients was $186.5 \pm 18.7$ (126-214) months.
In terms of educational status, $16,4 \%$ of those who attempted suicide $(\mathrm{n}=31)$ did not attend school, whereas $4.9 \%(n=7)$ of those in the control group did not attend school $(\mathbf{p}=\mathbf{0 . 0 0 2}) .17 \%(n=32)$ of the patients who attempted suicide lived either with their mother or father or separately from both $(\mathbf{p}=$ $\mathbf{0 . 0 2 2}$ ). The level of education of the mothers and 
fathers of the patients who attempted suicide was found significantly lower than the control group $(\mathbf{p}=\mathbf{0 , 0 1 5} ; \mathbf{p}=\mathbf{0 , 0 4}$, respectively). $71.8 \%(\mathrm{n}=155)$ of the patients were living in the city whereas $28.1 \%(\mathrm{n}=53)$ were living in the country $(\mathrm{p}=$ 0.204 ). There was no statistically significant difference between the two groups in terms of income levels and working conditions of parents.

\section{Findings on Suicide Attempt}

It was found that $168(89.3 \%)$ of the patients who attempted suicide had no previous suicide attempt; $15(7,9 \%)$ had a $2^{\text {nd }}$ suicide attempt, $3(1.6 \%)$ had a $3^{\text {rd }}$ suicide attempt, $1(0.5 \%)$ had a $4^{\text {th }}$ suicide attempt and $1(0.5 \%)$ had a $6^{\text {th }}$ suicide attempt. There was no statistically significant difference in the number of suicide attempts among the genders $(\mathrm{p}=0.12)$. The method of attempted suicide was drug intake in $98 \%$ of the cases. Three cases were taken to the emergency department with both multiple drug intake and with the use of cutting tool to damage the body, and one patient with suicide attempt by hanging himself.

$45.7 \%(n=86)$ of the cases were found to be taking more than one drug concomitantly. In suicide attempts, drugs affecting the central nervous system (antidepressant, antipsychotic and anxiolytic) $(\mathrm{n}=47 ; 25 \%)$ and analgesicantiinflammatory drugs $(\mathrm{n}=31 ; 16,4 \%)$ were found to be the most widely used agents.

In terms of months, it was found that patients attempted suicide mostly in December, March, June and September, when we examined the period between December 2011 and December 2012. When we examined the seasons of admission of patients, it was found that $29 \%$ of the patients attempted suicide in winter, and $20 \%$ of the patients attempted suicide in summer. There was no statistically significant difference in terms of the admission month and seasonal distribution over a period of one year $(\mathrm{p}=0.257)$.

When the reasons of suicide were examined in the patient group, $62,7 \%(\mathrm{n}=114)$ had problems with the family, $19,1 \%(\mathrm{n}=36)$ problems with friends, $9 \%(\mathrm{n}=17)$ problems with the school, $17 \%(\mathrm{n}=32)$ had problems with the family and friends, and no problems were identified in $4.7 \%(n=9)$ of the patients. From the perspective of gender, the most common reason was family problems in $57.8 \%$ of the females and $40 \%$ of the males.

\section{Smoking}

$32.3 \%$ of those who committed suicide stated that they smoked. It was found that $11.1 \%$ of the patients smoked rarely (a few times a month and a few times a week) and 21,2\% smoked frequently (every day). $4.9 \%$ of the control group stated they rarely smoked, whereas $8.5 \%$ stated they frequently smoked. There was a statistically significant difference in terms of smoking between the two groups $(\mathbf{p}<\mathbf{0 . 0 0 1})$

There was no statistically significant difference in terms of smoking between those who attempted suicide and the control group when they were compared by age groups, income levels, school attendance, and places of residence.

It was found that there was a statistically significant relationship between gender ( $p<0.001)$, living separately from mother and / or father $(p=0,048)$, repeatedly attempting suicide $(\mathrm{p}=0.012)$, mother and/or father being a smoker $(p<0.001)$ in those who attempted suicide.

Smoking among friends of those who attempted suicide was found to be $62,7 \%(\mathrm{n}=118)$. Smoking was observed to be $70.1 \%$ in males and $51.8 \%$ in females who had friends smoking $(\mathrm{p}=0.006)$.

\section{Alcohol and substance use}

$10,6 \%$ of those who attempted suicide said they used alcohol rarely (3-9 times in lifetime) and 6.2\% of them said they used alcohol frequently (more than 9 times in lifetime). 8,2\% of the control group stated they rarely took alcohol, whereas $4.2 \%$ stated they frequently took alcohol. $(\mathrm{p}=0.105)$.

There was no statistically significant difference in terms of alcohol use between those who attempted suicide and the control group when they were compared by age groups, income levels, school attendance, parents living together, alcohol or substance use by mother and/or father, Beck Depression Inventory scores and places of residence.

Substance use rate was found to be $11 \%$ as $6.7 \%$ of those who attempted suicide used substances rarely (2-5 times lifetime) and $4.3 \%$ of them used substances frequently (more than 5 times lifetime). $2,8 \%$ of the control group stated they rarely used substances, whereas $1,4 \%$ stated they frequently used substances $(\mathbf{p}=\mathbf{0 . 0 4 5})$.

$36.4 \%$ of the patients who attempted suicide repeatedly stated that they used a substance. 8.6\% of those who attempted suicide for the first time stated that they used a substance $(\mathbf{p}=\mathbf{0 . 0 0 1})$.

\section{Depression State}

According to the Beck Depression Inventory scores of those attempting suicide who said they use substances, it was found that $35,1 \%$ had no depression ( $<14$ points), 38\% had moderate depression (14-24 points) and 26,9\% had severe depression (> 25 points). There was statistically 
significant difference between the two groups $(\mathbf{p}=$ 0.001).

There was no statistically significant difference between the suicide attempt group and the control group in terms of smoking habits, alcohol and substance use, income level, the parent whom they lived with, where they lived, family type, alcohol use by parents, alcohol and substance use by friends, and Beck Depression Inventory scores.

\section{DISCUSSION}

The primary aim of this study was to identify the relationship between suicidal behavior and smoking, alcohol and substance use, and sociodemographic characteristics in adolescents aged 13-18. For this purpose, sociodemographic characteristics, smoking, alcohol and substance use of 188 adolescents who attempted suicide and 142 adolescents who constituted the control group were examined.

In this study, $82,3 \%$ of the adolescents who attempted suicide were girls and the girl/boy ratio were $4.3 / 1$. There is a consensus that suicide attempts are more frequent in women for all ages ${ }^{8-}$ 10.

When we investigated the education periods of those who attempted suicide, it was found that the education periods of the adolescents in our study were shorter than those in the control group. Shaffer ${ }^{11}$ and Brent ${ }^{12}$ found lower school success in adolescents who they examined for suicide attempts. Beautrais et al. ${ }^{13}$ reported that they found increased risk of suicide attempt in adolescents with poor education and low socioeconomic level. It was suggested that the short education period found in adolescents in our study who attempted suicide might depend on problems in family, school and friend relationships.

When we look at the places of residence, the vast majority of the cases in our study who attempted suicide lived in the city center. In a study, Lifshitz and Gavrilov ${ }^{14}$ reported that the vast majority of the 324 adolescents aged 12 to 18 years who applied to the hospital for suicide attempts between 1990 and 1998 were living in urban areas. The fact that the vast majority of the cases live in the city center may be due to the fact that urban people have easier access hospital services and that the social factors that instigate suicide are more common in cities.

$17 \%$ of adolescents who attempted suicide in our study were found to be from broken families. It is reported that the prevalence of suicide attempts in adolescents from broken families is quite high ${ }^{12,15}$. Turgay $^{16}$, and Yüksel et al. ${ }^{17}$ stated that, respectively, $54.6 \%$ and $36.4 \%$ of the children and adolescents who attempted suicide were from broken families. In this study also, in line with the literature, it was found that adolescents who attempted suicide were from broken families significantly more frequently than those in the control group.

In our study, it was seen that those who attempted suicide had a lower income level than those in the control group, but there was no statistically significant difference. There are several studies showing that there is no association between low socioeconomic level and suicidal behavior in studies conducted to date and that there is a relationship between suicide and suicide attempt and low socioeconomic level ${ }^{18,19}$.

It was found that the education levels of adolescents who attempted suicide were significantly lower than those in the control group. There are studies in the literature suggesting that low maternal education level increases the risk of suicide attempt ${ }^{20,21}$.

It was shown in a variety of researches that there is a close relationship between stressful life events and suicidal behavior in young people. It is known that both short-term and long-term life events play a triggering role in adolescent suicide attempts ${ }^{18,19,22,23}$. In particular, it is emphasized that a broken family structure and functioning are very important risk factors for adolescent suicides ${ }^{14,21,24}$. In our study, family problems were found to be the triggering factor for suicide attempts in more than half of the cases. In many studies on adolescent suicides in the literature, it is stated that friendship problems are an important risk factor for suicide attempts and it is suggested that this problem becomes more important in young people ${ }^{15,25,26}$.

In our study, the highest suicide attempt rate was in December (17.2\%), followed by March (13.8\%) and June and September (13.8\%). In terms of seasonal distribution, the highest number of attempts were in winter $(29 \%)$. Based on the data published by the State Institute of Statistics, it is understood that suicides among children were reported most in May, when analyzed in terms of distribution by months ${ }^{27}$. Kocabaş et al. ${ }^{28}$ reported that the number of suicide attempts was significantly high in April, May, June, and July and that these months are near the end of the semesters and are associated with the increase in the number of attempts.

All of the cases in our study attempted suicide by drug overdose. In a study conducted in the UK, it was reported that $90 \%$ of suicide attempts were committed by drug overdose ${ }^{29}$. In many studies conducted in our country it was also found that 
drug overdose was the most commonly used method in suicide attempts. Çuhadaroğlu et al. ${ }^{18}$ and Egrrilmez et al. ${ }^{25}$ stated that almost all of the adolescents attempting suicide attempted to commit suicide by drug overdose.

Looking at the number of suicide attempts in our study, it was found that $89.3 \%$ of cases had their first suicide attempt and $10.7 \%$ had repeated suicide attempts. The fact that $89.3 \%$ of the cases were the first suicide attempts can be a finding which was affected by the age variable. Previous suicide attempt is reported to be one of the biggest risk factors for suicide and suicide attempts ${ }^{30,31}$. In a study on suicide attempts by drug overdose, it was reported that $34 \%$ of patients had previously another attempt ${ }^{32}$. In another study on adolescent suicide attempts, it was reported that $21 \%$ of patients had previously another attempt ${ }^{24}$.

In our study, $32.4 \%$ of those who attempted suicide stated that they smoked. Smoking was found to be significantly higher when those who committed suicide were compared to the control group ( $p$ <0.001). In a study, Yaworski, D et al. ${ }^{33}$ investigated nicotine addiction and suicide attempts. Nicotine addiction level lifetime and a year ago were found to be associated with lifetime suicide attempts. However, many epidemiological and clinical studies have reported that there is a positive association between smoking status and suicide attempt and suicidal ideation ${ }^{34,35}$.

In this study, smoking rate was found to be high in those whose parents are smokers. In many studies, smoking habits have been found to be closely related to smoking habits of family members ${ }^{36,37}$. This makes it easier for students both to start smoking and become regular smokers.

In our study, alcohol use rate was found to be $14.8 \%$ in the suicide attempt group. There was no significant difference in terms of alcohol use between the control group and suicide attempt group. Studies have shown that alcohol or substance addiction increases the risk of suicide by five times ${ }^{38}$. The suicide rate of students who use alcohol and substances was found to be high in selfreport studies conducted in schools ${ }^{39}$.

In this study, adolescents who attempted suicide were found to have higher levels of alcohol or substance use in their parents. However, there was no statistically significant difference. In the literature, it is reported that those who bring up those who commit suicide have a higher rate of alcohol or substance abuse ${ }^{40,41}$. Cohen-Sandler et al. $^{23}$ showed that parents of suicidal children have a higher rate of alcohol/substance abuse (40\%) than the other groups in a study they conducted on suicidal, depressive, and psychotic controls. Eğrilmez $^{25}$ found that $25 \%$ of adolescents who attempted suicide had alcohol abuse or dependence in their families.

Substance use was found to be higher in the suicide attempt group than the control group. There is a strong relationship between substance use and completed suicide and attempted suicide in the literature ${ }^{42,43}$. In a study, Kandel et al. ${ }^{44}$ found that substance use, combined with depression, was the most important risk factor for suicide attempts.

There was no significant relationship between income level and substance use in our study. In one study, the risk of using volatile substances was found to be increased in primary school children with low income level, whereas the other items could not correlate with income level. In the same study, secondary school children from families with higher income levels were found to have a higher risk of stimulant use than children with lower income levels ${ }^{44}$.

In our study, a significant proportion of adolescents who attempted suicide were found to have a depressive disorder according to the scores they received from the Beck Depression Inventory, and this was found to be significantly higher than the controls. Most of the researches in the literature show that depression is the most important risk factor for suicide and suicide attempts during adolescence as in many other age groups ${ }^{18,45,46}$. Pfeffer et al. ${ }^{47}$ showed that the most common group of psychiatric diagnoses encountered among the adolescents who attempted suicide was mood disorders with a rate of $33.5 \%$. In another study, $42 \%$ of the adolescents who attempted suicide were found to have major depression ${ }^{48}$. As a result of interviews held with the families of adolescents who died due to suicide, it was found that $63-76 \%$ of them were individuals with a mood disorder ${ }^{49}$.

As a result, it was found that various factors play a role on suicidal behavior among adolescents. In addition to demographic factors such as gender, education level, family structure, family characteristics and parents' educational level, previous suicide attempt, smoking, alcohol and substance use, depressive mood and hopelessness were also found to be closely correlated with suicidal behavior. Further studies on determinants of suicidal behavior and determination of risk factors will guide professionals working on this subject to foresee suicide attempts. 


\section{REFERENCES}

1. Durkheim E. İntihar. Çeviren: Ozankaya Ö, Türkiye Tarih Kurumu Basımevi, Ankara 1986; s.14.

2. Bridge JA, Goldstein TR, Brent DA. Adolescent suicide and suicidal behavior. J Child Psychol Psyc 2006; 47: 372-394.

3. Shaffer D, Fisher P. The epidemiology of suicide in children and adolescents. J. Am Acad Child Adolesc Psyc 1981; 20: 545565.

4. Özgüven HD. Özkıyım riskinin değerlendirilmesi. İçinde: Yazıcı O, Oral ET, Vahip S. Depresyon Sağaltım Klavuzu Kaynak Kitabı, Türkiye Psikiyatri Derneği Yayınları. 2008; s.35-53.

5. Beck AT. An inventory for measuring depression. Arch Gen Psychiat 1961; 1: 561-571.

6. Beck AT, Weissman A, Lester D, Trexler L. The measurement of pessimism: the hopelessness scale. J Consult Clin Psychol 1974; 42: 861-865.

7. Öğel K, Tamar D, Evren C, Çakmak D. İstanbul'da Lise Gençleri Arasında Sigara, Alkol Ve Madde Kullanım Yaygınlığı. Klinik Psikiyatri 2000; 4, 242-245.

8. Oral G. İntihar ve adli bilimler. Yeni Symposium 1997; 35: 46-47.

9. Garfinkel BD, Forese A, Hood J. Suicide attempts in children and adolescents. Am J Psychiat 1982; 139: 1257-1261.

10. Hawton K. Assessment of suicide risk. Br J Psychiat 1987; 150: 145-153.

11. Shaffer D. Çocuk ve ergende depresif bozukluk ve özkıyım. İçinde: Sadock BJ. Sadock VA, Comprehensive textbook of psychiatry. 8. baskı Türkçe çevirisi. Güneş Kitabevi; 2007, 3262-3274.

12.Brent DA, Perper JA, Airman C. Alchool, firearms and suicide among youth. Jama 1987; 257: 3369-3372.

13. Beautris Al, Joyce PR, Mulder RT. Psychiatric illness in New Zealand sample of young people making serious suicide attempts. N Z Med J. 1998; 27:44-48.

14.Lifshitz M, Gavrilov V. Deliberate selfpoisoning in adolescents. Isr Med Assoc J 2002; 4: 252-254.

15.Pfeffer CR. Suicidal Behavior in Children and Adolescents: Cause and Management. Child and Adolescent Psychiatry, Lewis
M (ed), Williams \& Wilkins, Maryland 1996; 666-673.

16. Turgay A. Çocuk ve ergenlerde intihar girişimleri. Türk Psikiyatri Dergisi 1992; 3: 183-189.

17. Yüksel N, Özgentaş U, Çalangu S ve ark. Adelosanlarda intihar nedenleriyle ilgili bir çalışma, XXII. Ulusal Psikiyatri ve Nörolojik Bilimler Kongresi Kitab1 1985; s.220-230.

18. Çuhadaroğlu F, Sonuvar B. Adolesan Intiharlar1: Risk Faktörleri üzerine bir inceleme. Türk Psikiyat Derg, 1992; 3: 222-226.

19. Kotila L, Lonnquist J. Adolescents who make suicide attempts repeatedly. Acta Psychiatrica Scand 1987; 76: 389-393.

20. Mittendorfer-Rutz E, Rasmussen F, Wasserman D. Restricted fetal growth and adverse maternal psychosocial and socioeconomic conditions as risk factors for suicidal behaviour of offspring: a cohort study, Lancet, 2004; 364: 11351140 .

21. Kreitman N. Can suicide and parasuicide be prevented? J R Soc Med. 1989; 82: 648-652.

22. Brown JH. Suicide in Britain. Arch Gen Psychiat 1979; 36: 1119-1124.

23. Cohen-Sandier R, Berman AL, King RA. Life stress and symptomatology: Determinants of suicidal behavior in children. J Am Acad Child Psychiat 1982; 21: 178-186.

24. Sayar MK, Öztürk M, Acar B. Aşırı dozda ilaç alımıyla intihar girişiminde bulunan ergenlerde psikolojik etkenler. Klinik Psikofarmakoloji Bülteni 2000; 10: 133138.

25.Eğrilmez A. 15-19 Yaş Grubu Ergenlerin Suisid Girişimlerinde Predispozan Etkenler ve Aile Özellikleri. Uzmanlık Tezi, İzmir,1988.

26. Rich CL, Fowler RC, Fogarty LA et al. San Diego suicide study 2, relationship between diagnoses and stressors. Arch Gen Psychiat 1988; 45: 589-592.

27. Fidaner C, Fidaner H. Türkiye'de çocuk intiharlar1 epidemiyolojisi. Türk Psikiyatri Dergisi. 1992; 3: 255-260. 
28. Kocabaş Ö, Kavaklı T, Ecevit Ç, ve ark. Çocukluk çağ 1 intihar girişimleri. Ege Pediatri Bülteni 2004; 11: 119-124.

29. O'Connar R, Sheehy N. Suicide and gender. Mortality, 1997; 2: 239-254.

30. Oquendo MA, Kamali M, Ellis SP et al.: Adequacy of antidepressant treatment after discharge and the occurrence of suicidal acts in major depression: a prospective study. Am J Psychiat 2002; 159: 1746-1751.

31.Busch KA, Fawcett J, Jacobs DG. Clinical correlates of inpatient suicide. J Clin Psychiat 2003; 64: 14-19.

32. Sigara alışkanlıkları ve sigara ile mücadele kampanyası kamuoyu araştırması raporu, PİAR, Ocak 1988.

33. Yaworski D, Robinson J, Sareen J, Bolton J.M. The relation between nicotine dependence and suicide attempts in the general population. Can J Psychiat, 2011; 56: 161-170.

34. Tervdal A, Thelle D, Stensvold I, Leren P, Bjartveit K. Mortality in relation to smoking history: 13 years' follow-up of 68000 Norwegian men and women 35-49 years. J Clin Ep1demiol 1993; 46: 475487.

35.Paffenbarger Jr R.S., Lee M, Leung R. Physical activity and personal characteristics associated with depression and suicide in American college men. Acta Psychiatrica Scandinavica Supplementum 1994; 377: 16-22.

36. Göksel T, Cirit M, Bayındır Ü, Saçaklığlu F. Factor associated with smoking among high school students. Eur Respir J 1999; 14: 217.

37. Metintaş S, Sarıboyacı MA, Nuhoğlu S ve ark. Eskişehir ilindeki üniversite öğrencilerinde sigara içme alışkanlığına ait özellikler. Tüberküloz ve Toraks 1996; 44: 77-83.

38. Türkçapar MH, Akdemir A, Elverici ŞK ve arkadaşları. Yatarak tedavi gören bir grup alkol bağımlısında ek psikiyatrik hastalıklar, kişilik bozuklukları, depresyon ve kayg1 düzeyleri. 3 P Dergisi 1997; 5: 29-34.
39. Doğan YB. Alkol kullanımı ve intihar davranışı. İzmir: Ege Tıp Bülteni. Özel Sayı. 2000; s.1-6.

40. Johnsson E, Fridell M. Suicide attempts in a cohort of drug abusers: A 5-year followup study. Acta Psychiatr Scand, 1997; 96: 362-366.

41. Rossow I, Lauritzen G. Shattered childhood: A key issue in suicidal behavior among drug addicts. Addiction, 2001; 96: 227-240.

42.Eaton DK, Kann L, Kinchen S et al. Youth Risk Behavior Surveillance - United States, 2007. MMWR Surveill Summ 2008; 57: 1-131.

43. Yazman Ü. Lise gençliğinin psikoaktif maddelere bakısı ve kullanım oranlarının Türkiye-İstanbul örneği ile incelenmesi. Uzmanlık tezi. İstanbul: Bakırköy Ruh ve Sinir Hastalıkları Hastanesi; 1995.

44. Ögel K, Çorapçıoglu A, Sır A ve ark. Türkiye'de Dokuz İlde İlk ve Ortaöğretim Öğrencilerinde Tütün, Alkol Ve Madde Kullanım Yaygınlıgı. Türk Psikiyatri Dergisi 2004; 15: 112-8.

45. Morrissey RF, Dicker R, Abikoff $\mathrm{H}$ et al. Hospitalizing the suicidal adolescent, an empirical investigation of decisionmaking criteria. J Am Acad Child Adoles Psychiat 1995; 34: 902-911.

46. Robbins D, Ailesi NE. Depressive symptoms and suicidal behavior in adolescents. Am J Psychiat 1985; 142: 588-592.

47.Pfeffer CR, Newcom, Kaplan G et al. Suicidal behavior in adolescent psychiatric inpatients. J Am Acad Child Adolesc Psychiat 1988; 3: 357-361.

48. Rotheram-Borus MJ. Evaluation of imminent danger for suicide among youth. Am J Otrhopsychiatr 1987; 57: 102-110.

49. Bakim B, Karamustafalığlu K, Akpınar A. Alkol ve diğer madde kullanım bozukluklarında intihar girişimleri ve tamamlanmış intihar. Journal of Dependence, 2007; 8: 91-96. 